\title{
2-1-86 高周波才ージオメーターによる㯖力检查成積
}

はじめに

○関和夫富团善台知野整右(慈大)

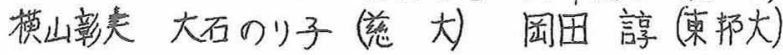

人间の耳は個体差、年令等にもよるが成人では16へルッがら20000ヘルソ程度まで聞下え ると云わ北ている。今回私達は米国製の高周没自記才ージオメータ一を使用し，此翰的䭽 音に曝さ北ずに生活を堂大んでいる，岩手景宫古市郊外の住民(20才か535才)12洛(236耳)文效 鱼に聴力湌查を施行, 若干の模查結果を得たのでここに報告する。

使用㜻器と祥查方法

RUDOMOSE ARJ-4HF HIGH FREQUENCY AUDIOMET $E R($ 国 I)

FREQUENCY: $144 \quad 6 \quad 8 \quad 1011$

$\begin{array}{llllll}12 & 13 & 14 & 15 & 16 & 18\end{array}$

HEARING LOSS RANGE

$-20 \mathrm{~dB} \sim 80 \mathrm{~dB} ; \quad 4-15 \mathrm{KHz}$

$-30 \mathrm{~dB} \sim 70 \mathrm{~dB} ; \quad 16 \sim 18 \mathrm{KHz}$

CALIBRATION:500Hzt56 KHzに わたって正常市㮦力を有するHigh. School Students (国I)

のThreshold をもとにしミといわ北るものである。

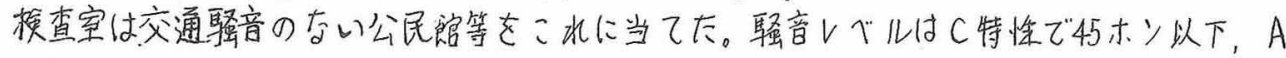
特性で30ホン以下であった。

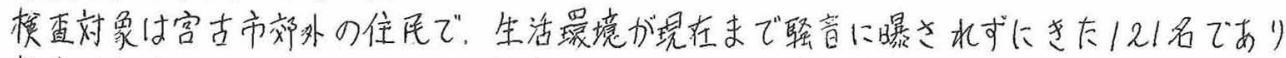

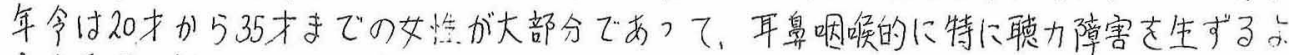
う柰原因加認りら北志いものに限定した。

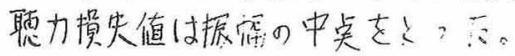

校查結果

(I)各高周波とこ北を㽙きうる人数(\%)

$11 \mathrm{KHz} \quad 1128(92.5 \%) \quad 12 \mathrm{KHz} \quad 1118$ 名(91.8\%) $13 \mathrm{KHz} \quad 988$ 名 $(80.4 \%) \quad 14 \mathrm{KHz}_{2} \quad 899$ 名 $(73.5 \%)$

$15 \mathrm{KHz} \quad 833$ 名 $(68.6 \%) \quad 16 \mathrm{KHz} \quad 488(39.6 \%)$

$18 \mathrm{KHz} \quad 40,8(33.0 \%)$

国2が示すごとく、12KHzまで(む殆んど大

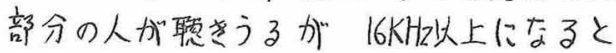
㯖:えてこる人数が急激に減少しているこ

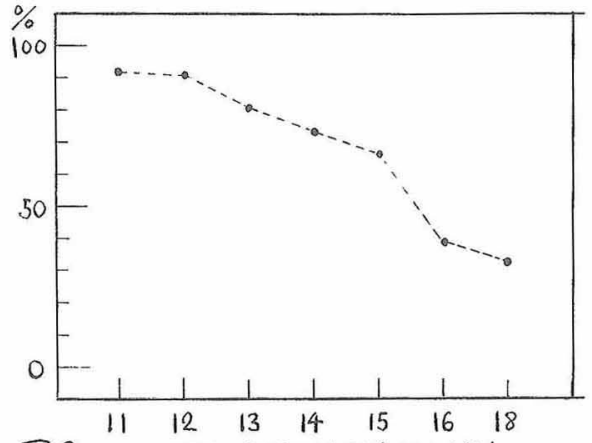

国2 FREQUENCY IN KHZ とが为かる。 
(II) 各周波数の聴力摸失值（121名 236耳）

$\begin{array}{ll}4 \mathrm{KHz} \text { (233耳) } & 22.0 \mathrm{~dB} \\ 8 \mathrm{KHz} \text { (232耳) } & 30.1 \mathrm{~dB} \\ 10 \mathrm{KHz} \text { (233耳) } & 26.2 \mathrm{~dB} \\ 11 \mathrm{KHz} \text { (230耳) } & 29.6 \mathrm{~dB} \\ 12 \mathrm{KHz} \text { (210耳) } & 36.3 \mathrm{~dB} \\ 13 \mathrm{KHz}(188 耳) & 39.9 \mathrm{~dB} \\ 14 \mathrm{KHz}(163 \text { 耳) } & 40.5 \mathrm{~dB} \\ 15 \mathrm{~K} \mathrm{~Hz} \text { (136耳) } & 44.0 \mathrm{~dB} \\ 16 \mathrm{KHz} \text { (72耳) } & 39.5 \mathrm{~dB} \\ 18 \mathrm{KHz} \text { (58耳) } & 41.9 \mathrm{~dB}\end{array}$

因了加5专13 KHz以上は余り㮦力 掅失值に差がないことが小かる。

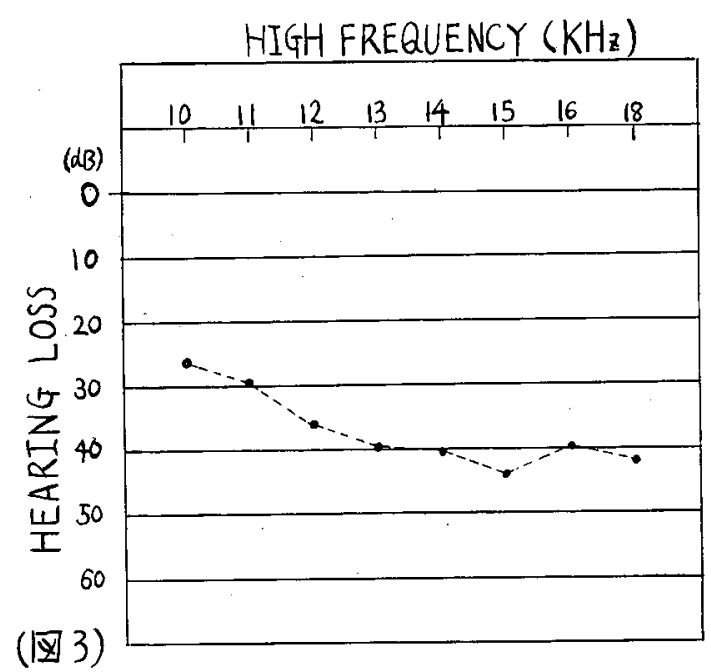

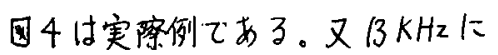
おいてD洱らしき吉のが钼5北。气れらの 数は95名中28名(约290)1:镜5 水布。

\section{まとめ}

人闹の可聘周波数は16 Hz か $520 \mathrm{KHz}$ といわ水 ているが、今回の私達の楧雷において18 KHz まで搞える人は $33 \%$ で、16 K

珤之る人粼は急激に減少する （四4）

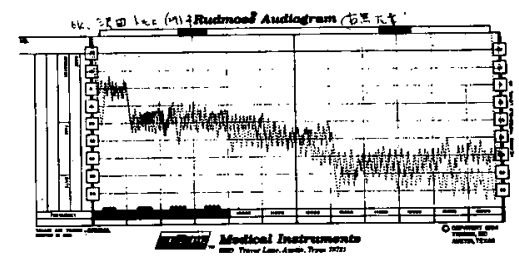

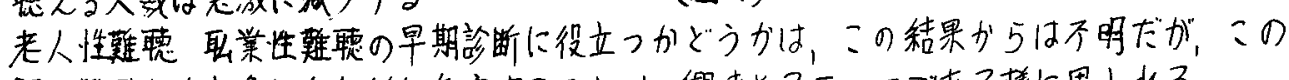
種の難聴者を奶象に経年的に追究することは、舆味あるテーマである梯に思小北る。 